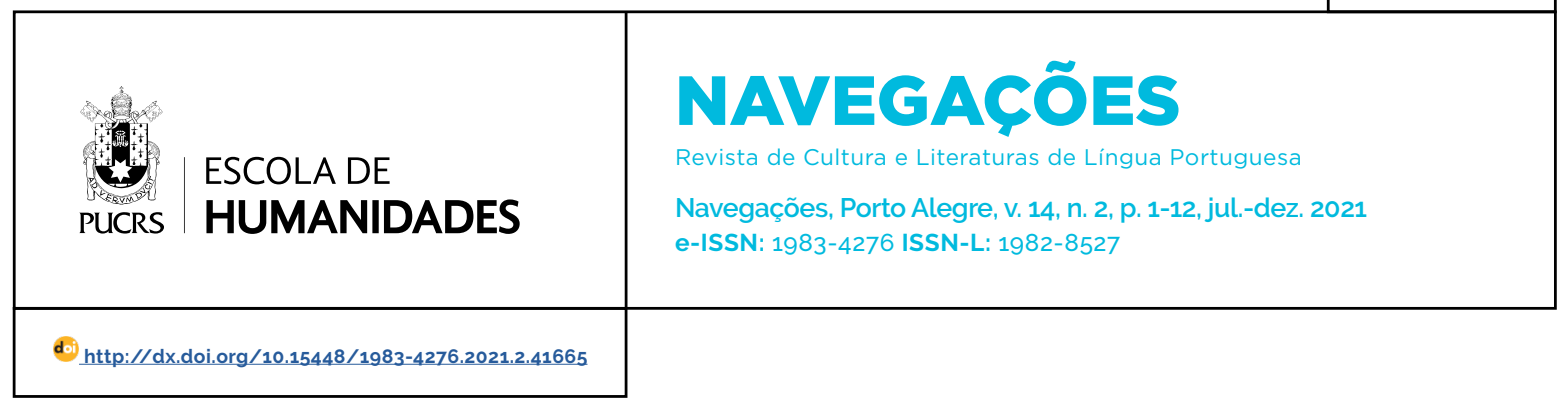

SEÇÃO: ENSAIOS

\title{
A representação do cidadão (português) medíocre em Dulce Maria Cardoso
}

\author{
The representation of the mediocre (portuguese) citizen in Dulce Maria Cardoso
}

\section{Gabriela Cristina \\ Borborema Bozzo ${ }^{1}$}

orcid.org/0000-0002-1843-3360

gabrielaborborema@live.com

Recebido em: 30 ago. 2021. Aprovado em: 1 nov. 2021. Publicado em: 16 dez. 2021.
Resumo: O cidadão (português) mediocre é aquele que abdica da própria individualidade, se aliena, se rende ao sistema socioeconômico e é submisso. Assim, o cidadão (português) medíocre figura, em uma seção da obra de Dulce Maria Cardoso, um ser sem nome, sem identidade fixa, chamado de "funcionário", que são todos parecidos uns com os outros, para desidentificar a humanidade deles. Nosso corpus, por sua vez, é composto por Campo de sangue e Os meus sentimentos, os dois primeiros romances publicados pela escritora portuguesa contemporânea. Objetivamos, no presente artigo, delinear o perfil desses ditos "funcionários", bem como investigar sua presença e função no corpus. Para tanto, embasar-nos-emos em O que é a não pertença e como se dá a sua construção em Os meus sentimentos, de Dulce Maria Cardoso, de Gabriela Cristina Borborema Bozzo; Manifesto comunista, de Marx e Engels, Adorno e Freud em "Civilização e alienação: diálogo com Freud e Adorno" (2006), de Danelon e O romance português contemporâneo (1950-2010), de Miguel Real.

Palavras-chave: Literatura portuguesa contemporânea. Campo de sangue. Os meus sentimentos. Cidadão medíocre.

Abstract: The mediocre (Portuguese) citizen is one who abdicates his own individuality, alienates himself, surrenders to the socioeconomic system and is submissive. Thus, the mediocre (Portuguese) citizen figures, in a section of Dulce Maria Cardoso's work, a being without a name, without a fixed identity, called "employee", who are all similar to each other, in order to de-identify their humanity. Our corpus, in turn, is composed of Campo de sangue and Os meus sentimentos, the first two novels published by the contemporary Portuguese writer. In this article, we aim to outline the profile of these so-called "employees", as well as investigate their presence and function in the corpus. In order to do so, we will base ourselves on O que é a não-pertença e como se dá sua construção em Os meus sentimentos, de Dulce Maria Cardoso, by Gabriela Cristina Borborema Bozzo; Manifesto comunista, by Marx and Engels, Adorno and Freud in "Civilização e alienação: diálogo com Freud e Adorno" (2006), by Danelon and O romance português contemporâneo (1950-2010), by Miguel Real.

Keywords: Contemporary Portuguese Literature. Campo de sangue. Os meus sentimentos. Mediocre citizen.

\section{Introdução}

O cidadão (português) mediocre seria um simulacro de um homem comum, mediano, que abdicou de sua identidade, se alienou, se submeteu e é regido pelo sistema socioeconômico vigente. Por dela ter abdicado, não tem identidade fixa e que, com o efeito manada, não importa o quanto tem, materialmente; sempre deseja mais. 
Mas o preço do conforto básico - para o funcionário de baixo escalão, o proletariado - e do luxo - para o de alto escalão, o burguês - está em abdicar de quem se é. Nessa condição, não se tem autoconhecimento ou percepção da vida a sua volta e, mais do que isso, está aprisionado à sua infelicidade.

Por sua vez, nosso corpus é constituído por dois romances de Dulce Maria Cardoso: Campo de sangue (2018), primeiramente publicado em 2001, figurando o primeiro romance da escritora portuguesa contemporânea, e Os meus sentimentos (2012), cuja primeira edição, de 2005, faz dele a segunda produção literária da romancista.

Campo de sangue apresenta, com narrador heterodiegético (com exceção de um capítulo autodiegético), a história de um protagonista sem nome, como o são todas as personagens do romance, excetuando-se Eva, a ex-mulher do protagonista. Da vida vadia à obsessão e à loucura, acompanhamos esse protagonista com capítulos intercalados entre sua história e as quatro mulheres de sua vida - a saber, a ex-mulher, a mãe, a senhoria e a rapariga com quem se envolve e que dele engravida - a esperarem em uma sala de um hospital psiquiátrico (onde ele está internado após cometer feminicidio) para depor suas relações e percepções do assassino ao médico da instituição.

Já Os meus sentimentos apresenta, por meio de uma narradora autodiegética, a história de Violeta que, após um acidente automobilístico na estrada, conta o que poderia ser seu último dia de vida em ordem inversa e, entremeado a esse discurso, deixa escapar a sua história: uma mulher rejeitada em todas as esferas de sua vida. Apesar de narrar sua própria morte, nossa leitura é de que a narradora-protagonista se encontra viva durante todo do discurso narrativo. Apoiamos nossa interpretação na referência que ela faz à posição desconfortável em que se encontra no carro - de cabeça para baixo, presa pelo cinto de segurança - mesmo após narrar sua morte. Portanto, do capitulo um ao seis ela narra o que seria seu último dia de vida, do sétimo ao décimo, projeções da sua morte e no décimo primeiro, seu encontro com a paz. Entremeado ao discurso todo, temos a história de sua vida que Violeta nos deixa escapar, fazendo com que o leitor monte um quebra-cabeças para entender sua história por meio de seu discurso.

Objetivamos, nesse interim, apresentar a noção de extremo "eu" e extremo "mim", pautada na psicologia social de George H. Mead, bem como delinear o perfil desse cidadão (português) mediocre e averiguar seu aparecimento e função nos romances, que compõem nosso corpus. Apesar de falarmos de um cidadão português mediocre, o aparato teórico tem uma perspectiva mais universal, conferindo o aspecto da nacionalidade por meio daquela da escritora.

Para tanto, embasamo-nos, primeiramente, em O que é a não pertença e como se dá a sua construção em Os meus sentimentos, de Dulce Maria Cardoso, de Gabriela Cristina Borborema Bozzo. O livro nos será útil para entender, no sentido psicológico, a questão do cidadão mediocre. Quanto ao conformismo social e político desses funcionários, assim chamados nos romances, a baliza teórica é constituída por Manifesto comunista, de Marx e Engels. Já a alienação desses seres será averiguada segundo os postulados de Adorno e Freud em "Civilização e alienação: diálogo com Freud e Adorno" (2006), de Danelon. Por fim, a história do romance português recente será averiguada por meio de O romance português contemporâneo (1950-2010), de Miguel Real.

\section{Breves considerações sobre o corpus Campo de sangue}

O primeiro romance de Dulce Maria Cardoso apresenta uma narrativa intercalada. Ora, capitulos sobre a vida do protagonista em busca da rapariga bonita, que na verdade são cinco mulheres - a namorada do dono da esplanada, a jovem da praia, a moça do metrô, aquela com quem ele se envolve e aquela que ele mata, acreditando ser a com quem se envolveu -, mas que para ele, havia uma única rapariga bonita, todas em uma só. Ora, capitulos com as quatro mulheres da sua vida - a mãe, a ex-mulher, a rapariga com quem se envolveu e que está grávida dele e a senhoria da pensão onde ele morava. As quatro 
aguardam para depor sobre o assassinato que ele cometera. De início, entende-se que estão em uma delegacia e que deporão a um delegado. Depois, entende-se que estão no hospital psiquiátrico e quem lhes entrevistará será um médico.

Os capítulos em que as quatro mulheres esperam ser identificadas e, posteriormente, chamadas para depor são os capítulos que nos interessam nessa investigação, uma vez que são neles em que os "funcionários" aparecem.

\section{Os meus sentimentos}

O segundo romance da escritora apresenta uma narrativa em primeira pessoa em que, em um jorro de consciência, Violeta conta, após um acidente automobilístico, o que poderia ser seu último dia de vida em ordem inversa e, nessa narrativa primeira, deixa escapar a história de sua vida: uma mulher obesa rejeitada em todas as esferas de sua vida.

A parte mais interessante, para fins de averiguação do cidadão (português) mediocre nesse romance está no capítulo cinco, em que Violeta vai ao banco vender a casa dos pais com a esperança de uma nova vida, livrando-se dos fantasmas do passado.

\section{O extremo "mim" como causa da mediocridade}

Em estudos prévios (dissertação de mestrado), definimos a não pertença - sentimento que o individuo experiencia quando não se sente parte do meio em que está inserido - como fruto do desequilibrio entre as fases do self proposto por George H. Mead no livro Mente, self e sociedade, organizado por Charles W. Morris. O self, sintetizando, seria a parte do individuo que se desenvolve socialmente. Assim, para o psicólogo social Mead, existem duas fases do self: o "eu" e o "mim". Como afirma Bozzo (2020, p. 8-9):

Em primeiro lugar, o self, de acordo com Mead (apud MORRIS, 2010, p. 151), é o processo social em que a personalidade do sujeito se desenvolve. Não é o organismo fisiológico em si, não está presente desde o nascimento. É a mente autoconsciente que se desenvolve no sujeito a partir das suas experiências e atividades sociais, ou seja, de sua relação com o processo social e os demais membros da sociedade nele envolvidos. O self é o processo de interação entre o individuo e os outros, realizando-se na conduta do sujeito, no diálogo entre as suas fases, sendo elas o "eu" e o "mim". Nesse sentido, em sintese, o "eu" é a fase do self que constitui o que há de peculiar no indivíduo: impulsos, desejos, características únicas, sua essência. Ele é moldado para as interações sociais pelo "mim", que é a internalização dos valores, expectativas e atitudes da sociedade em que o sujeito está inserido. Por sua vez, o "mim" é a fase do self constituida pela internalização das atitudes do "outro generalizado", ou seja, as atitudes da comunidade inteira. Esse "outro generalizado" constitui a resposta comum e a atitude organizada quanto às instituições de uma sociedade. Essas instituições são assimiladas pelo sujeito em sua conduta, e são essas assimilações e o pertencimento à comunidade que possibilitam-no ser uma personalidade. Desse modo, através desse "outro generalizado", a comunidade influencia largamente o comportamento dos individuos. Assim, o self se desenvolve por completo na medida em que se torna um reflexo individual dos padrões comportamentais de uma sociedade ou grupo.

Assim, o "eu" é a fase do self que constitui o que há de peculiar no individuo: impulsos, desejos, características únicas, sua essência. Ele é moldado para as interações sociais pelo "mim", que é a internalização dos valores, expectativas e atitudes da sociedade em que o sujeito está inserido. Assim, propomos que há o extremo "eu" e o extremo "mim" que resultam na não pertença (desequilibrio entre as fases do self).

Desse modo, o extremo "eu" praticaria a atitude do coletivo (excluí-lo) consigo mesmo, autoexilando-se socialmente. Já o extremo "mim" seria a automutilação identitária praticada por aqueles que, a todo custo, almejam a pertença. Como afirma Bozzo (2020, p. 11-12)

Desse modo, a prevalência do "mim" na experiência do individuo resulta, muitas vezes, do instinto da pertença. Nesse sentido, por exemplo, a religião é uma instituição que supre esse instinto, pois, através dela, o sujeito experimenta a sensação de pertencimento a uma comunidade. Segundo Mead (apud MORRIS, 2010, p. 237), "essa é a experiência por trás dos extremos às vezes histéricos que pertencem às convenções." Logo, há predominância do "mim" nessa conduta pela devoção a tal comunidade e pela necessidade de se ajustar a ela. Assim sendo, cremos que quando o ajuste excessivo à comunidade mutila a individualidade do sujeito, ele tem uma conduta extremada no "mim", gerando um pertencimento forçado que reflete a real não-pertença do indivíduo. Já a conduta extremada no "eu" resulta na 
sensação da não-pertença, uma vez que, levada ao extremo, a predominância do "eu" constitui uma existência que não se ajusta excessivamente à sociedade, diferente do "mim", mas que pratica consigo a exclusão que sente da sociedade. Nesse caso, o individuo internaliza também as expectativas sociais, mas essas são excludentes com relação a ele, seja por pertencer a um grupo de minorias ou por apenas pensar diferente. Em resposta a isso, o individuo concorda em não pertencer e se exclui. Contudo, ele não deixa de assumir a atitude do outro, pois quando se exclui por se sentir excluido, a não-pertença faz com que o indivíduo aja consigo como a sociedade age com ele.

Desse modo, considerando as proposições colocadas sobre o extremo "eu" e o extremo "mim" e a não pertença, pode-se inferir que o cidadão (português) mediocre, no corpus, é apresentado como extremo "mim" - aquele que apenas cumpre regras, que não se impõem, que não tem nome e que, mesmo quando figura um funcionário de alto escalão, percebe-se que o poder e o dinheiro não lhes trazem felicidade.

Já a narradora-protagonista de Os meus sentimentos, Violeta, representa o extremo "eu", e é a partir dessa perspectiva autoexilante que denuncia quem é extremo "mim" - inclusive os "funcionários" - pela sua busca incessante pela pertença.

\section{A alienação e a mediocridade como condição social e histórica}

O panorama aqui exposto é conduzido pelas considerações de Danelon em "Civilização e alienação: o diálogo com Freud e Adorno" (2006).

Danelon afirma que, com a publicação de Dialética do esclarecimento, de Adorno e Horkheimer, resgata-se o conceito de esclarecimento, que, para os autores, é o processo de dominação dos homens e desencantamento do mundo. Se, por um lado, o esclarecimento permitiu o poder dos homens sobre a natureza, por outro, ele é responsável pela alienação do homem - não à natureza um dia hostil a ele, mas a um sistema econômico e social extremamente inumano e violento. Assim, Danelon (2006, p. 88) afirma:

\begin{abstract}
Assim, o esclarecimento adquire a significação de desencantamento do mundo, e o produto do esclarecimento - uma sociedade desenvolvida - adquire o sentido de dominação dos homens pelo sistema econômico/social. [...] ao mesmo tempo em que reveste os homens do poder de dominadores do mundo, reveste-os, também, com o manto de seres alienados e submissos, que perderam frente ao sistema aquilo que tinham de mais valioso: a sua individualidade [...] o processo de esclarecimento do homem traz em seu bojo o processo de diluição do homem individual numa massa sem identidade própria.
\end{abstract}

Logo, a sociedade desenvolvida, a tecnologia, a fruição da natureza pelo homem têm o "outro lado da moeda": a dominação dos seres humanos pelo sistema econômico e social, a alienação, a submissão e a perda de individualidade, como ocorre com o sujeito que tem a atitude do extremo "mim" supracitada, bem como com o cidadão movido às obrigações básicas proposto por Real.

Já no diálogo entre Adorno e Freud (Mal-estar da civilização, 1930), sob a ótica do filósofo e do psicanalista, o conforto que temos hoje é uma troca. O que damos, nessa troca pelo conforto, é justamente "a escravidão diária no trabalho, a alienação no trabalho, no lazer, no consumo, na repressão dos desejos do homem, na ausência de liberdade, na diluição do homem numa massa sem rosto ou identidade." (DANELON, 2006, p. 91).

\section{E é essa a dialética de Adorno:}

[...] ela produz conforto e miséria, saúde e doença, riqueza e pobreza, vida e morte. É essa a ambigüidade da nossa civilização "racional". Dessa forma, a nossa civilização desenvolvida sustenta-se em bases racionais que, por sua vez, produzem, também, estados de profunda barbárie (DANELON, 2006, p. 92).

Logo, o surgimento da civilização possui dois lados antagônicos, mas indissociáveis. A felicidade, nesse processo, é deixada de lado, pois:

No projeto da civilização não cabe aos homens ser felizes, pois a felicidade é individual e contingente e a organização da sociedade não pode depender da satisfação do indivíduo. Nesse sentido, a vida na civilização é formada por homens ressentidos, resignados e frustrados, que cotidianamente reprimem seus desejos que iriam thes proporcionar prazer. 
para realizar as exigências morais, religiosas e econômicas necessárias à manutenção da civilização (DANELON, 2006, p. 95)

Assim, abdica-se da felicidade em prol da organização social. Logo, essa civilização é formada por pessoas conformadas, frustradas, infelizes que cumprem seus deveres e esquecem de seus desejos individuais.

Por sua vez, Freud, no livro referido, aborda a insanidade do homem moderno: "seu drama existencial é resultado do conflito entre as exigências pulsionais e as leis que normatizam as relações dos individuos entre si. A perene interdição do desejo produz sujeitos "doentes", incomodados com o mundo e com a própria vida." (DANELON, 2006, p. 97). Assim, o homem constrói sua própria frustração:

Numa relação dialética com a civilização, o homem é produto e produtor desse mundo todo organizado em regras, costumes e leis que nos permite viver cada dia. Essa mesma civilização que nós produzimos para tornar possivel a perpetuação de nossa espécie é produtora, por outro lado, desse sujeito doente, infeliz, fracionado em seu desejo e condenado a se deparar constantemente com a falta (DANELON, 2006, p. 97).

Desse modo, o processo civilizatório voltou-se contra seu criador. É o que afirma Danelon (2006, p. 100), ainda sobre Freud:

O processo de desenvolvimento social emanado da racionalidade humana transformou-se num rolo compressor que esmaga a possibilidade de satisfação do homem. De criador da civilização, o homem moderno passou a ser criatura submissa e alienada à sua própria criação. Os ganhos de bem-estar propiciados pela civilização através das comunicações, transporte, medicina, ciência e tecnologia, funcionam como paliativos ao mal-estar do homem.

O rolo compressor são as obrigações sociais (trabalho), morais (religião e cumprimento de leis) e familiares (papéis de gênero que, infelizmente, ainda reverberam). Assim, as conquistas tecnológicas e científicas do homem são paliativas do mal-estar que a civilização provoca no homem. Desse modo, para unir Adorno e Freud novamente, Danelon propõe (2006, p. 101):
Na vida em civilização, o que resta aos homens é somente o contentamento com o tipo de prazer que a própria sociedade cria e oferece aos homens. Em sintese, da mesma forma que a civilização criou a massificação do consumo, ela criou, também, a massificação do prazer, isto é, o prazer individual deve estar submetido ao tipo de prazer proporcionado pela civilização.

A submissão do individual ao civilizatório, aqui - e em outros momentos da exposição de Danelon -, dialoga com a atitude de automutilação identitária da conduta do extremo "mim" que propomos embasando-nos nas fases do self de Mead. É esse o poder que o coletivo tem sobre o individual: o homem mutila sua própria individualidade para pertencer a uma civilização que, afinal, the causa mal-estar.

Por fim, convém salientar que a alienação e a castração a que o homem é submetido no processo civilizatório pode ser relacionada ao homem mediocre social e politicamente. Mediocre, mediano, comum. Esse é o homem da civilização moderna: acomodado às condições que lhe são impostas para usufruir da natureza e seus confortos; pouco politicamente engajado pela inércia de pertencer à classe burguesa ou proletária, ambas vendedoras do tempo em jornadas de trabalhos exaustivas em prol do conforto que, para a burguesia, é maior; já para o proletariado, é o básico: alimentação, moradia, saúde etc. Apoiamos nossas considerações no seguinte trecho do Manifesto comunista de Marx e Engels (1999, p. 7):

\begin{abstract}
Homem livre e escravo, patrício e plebeu, barão e servo, mestre de corporação e companheiro, numa palavra, opressores e oprimidos, em constante oposição, têm vivido numa guerra ininterrupta, ora franca, ora disfarçada; uma guerra que terminou sempre, ou por uma transformação revolucionária, da sociedade inteira, ou pela destruição das classes em luta.
\end{abstract}

Contudo, a luta de classes de Marx e Engels aqui assume um aspecto metafórico. É o que observaremos mais adiante nas reflexões de Violeta, narradora-protagonista de Os meus sentimentos, sobre as diferenças de classes sociais dos funcionários - todos sem nome - do banco onde vende a casa de seus pais. 
É interessante notar o contraste entre Adorno/ Freud e Marx/Engels, uma vez que os primeiros falam das amarras geradas pela civilização no homem e os segundos argumentam sobre a luta de classes. Ela existe, sim. Como abordamos, aos mais abastados, com a civilização, perde-se a individualidade em prol do conforto, do trabalho bem remunerado, do dinheiro. Já no caso do proletariado, vende-se a individualidade por meio do trabalho pelo básico, como moradia e alimentação.

\section{Quem é o cidadão (português) medíocre?}

O cidadão (português) medíocre - mediano - seria aquele indivíduo cuja necessidade de pertencer ao meio em que está inserido ultrapassa seus impulsos e desejos, resultando em uma automutilação identitária para caber nos moldes impostos socialmente. Assim, segundo a psicologia social de Mead apresentada e nossa proposição de extremos "eu" e "mim", podemos inferir que esse cidadão (português) mediocre figura um indivíduo que vive como extremo "mim", devido à prática da automutilação identitária a fim de pertencer à sociedade em que vive, como supracitado.

A fim de entender a relação entre esse sujeito mediano e a história do romance português contemporâneo, faremos uso de O romance português contemporâneo (1950-2010), de Miguel Real. O autor fala sobre o aspecto universal desse romance quando afirma: "Assim, o romance, como forma de arte, seja enquanto retrato e manifestação de traços psicológicos humanos, seja enquanto revelação de uma realidade social, seja enquanto expressão de um universo cultural, é igualmente universal" (REAL, 2012, p. 9). É por essa universalidade que nos referimos a esse indivíduo como cidadão (português) mediocre: português porque se trata de romances portugueses e parênteses pela universalidade do romance.

Abordando essa internacionalização do romance, Real destaca quatro aspectos do romance português:

Em sintese, a nova narrativa portuguesa não retrata já um Portugal fechado sobre si próprio, antes um Portugal europeu, global, com tendências sociais e problemas psicológicos semelhantes aos dos europeus. Neste novo Portugal, evidenciam-se, nos conteúdos dos romances [...], quatro características sociais, paradoxalmente já denunciadas na obra de Eça de Queirós: uma democracia sem valor nem mérito, a omnipotência do dinheiro, o império de uma educação sem alma e o esboroamento dos antigos valores humanistas europeus e portugueses de generosidade, de honestidade, de espiritualidade, evidenciando o retrato de um cidadão, não lúcido, mas iletrado, de mente confusa, não socialmente ativo, mas indiferentista, não comprometido politicamente, mas partidariamente oportunista (REAL, 2012, p. 13, grifo nosso).

O retrato do cidadão em destaque no trecho se aproxima bastante do cidadão que tentamos delinear nesse tópico. A confusão mental, o descompromisso político, o oportunismo são aspectos daqueles que, para caber nos moldes sociais, automutilam-se identitariamente. Real reitera:

\begin{abstract}
Deste modo, como no final do século XIX, as personagens portuguesas de romances portugueses, ainda que situadas num tempo e num espaço portugueses, perderam, na quase totalidade dos romances publicados, o seu vínculo ideológico «portuguesista» (ou nacionalista) [...] para se estatuírem como seres humanos universais, indiferentes aos pormenores locais, trajando, comendo, trabalhando, guerreando e amando como cidadãos do mundo (REAL, 2012. p. 13-14, grifo nosso).
\end{abstract}

Como cidadãos do mundo, o cidadão (português) mediocre, como o sujeito descrito no trecho em destaque, vive no piloto automático social, sua busca incessante por pertencimento e consequente automutilação identitária são inconscientes.

A mediocridade de que falamos é citada por Real (2012, p. 68): "Porque fruto de uma época vulgar e mediocre como a nossa, que nada exige do cidadão senão o cumprimento da lei e o pagamento de impostos [...]." Sendo nosso tempo medíocre e esse cidadão de que falamos fruto dele, ele também se torna medíocre. E as exigências em pauta são justamente aquelas que levam esse cidadão ao piloto automático: pagamento de impostos, o que nos leva às compras e ao consumismo exacerbado, que torna esse cidadão insaciável materialmente.

Portanto, esse cidadão (português) mediocre nada mais é do que o sujeito mediano, figurando o 
extremo "mim" por nós apresentado e dialogando com os conceitos propostos por Real em sua obra.

Relacionando esse cidadão (português) mediocre às ideias discutidas por Danelon, temos o fato de que esse sujeito mediano de que tratamos é aquele submetido ao sistema social e econômico que domina os seres humanos e, com isso, aliena-se e perde a própria individualidade.

A venda de nosso tempo (trabalho) em prol de conforto mínimo (proletariado) e luxo (burguês) representa também a alienação nesse trabalho, no consumo, na abdicação da liberdade e na repressão dos desejos da humanidade, massificada em um todo sem rosto ou identidade. Essa repressão dos desejos pode ser relacionada à baixa atividade da fase do self "eu", por se tratar de pessoas que figuram extremos "mim". O sujeito mediano, portanto, abdica de si e se transforma em um todo social. Apesar de pertencer, perde sua identidade, seu rosto, seus impulsos. É neste momento que ocorre a automutilação identitária de que falamos.

\section{Os funcionários sem nome de Dulce Maria Cardoso e sua mediocridade como denúncia de uma sociedade desindividualizante}

Iniciando por Campo de sangue, seguindo a ordem de publicação, temos os funcionários não diferenciados entre si que abordam as mulheres na sala de espera para depor ao psiquiatra sobre o homem internado, nosso protagonista assassino. Eles compõem o proletariado no romance, a classe mais baixa, o que é possivel perceber quando afirmam que a espera das mulheres não depende deles e que estão apenas cumprindo ordens, como veremos adiante. São homens que perdem sua individualidade em prol do conforto básico: moradia, alimentação etc., como visto nas afirmações de Danelon. E são aqueles que figuram os extremos "mim": seguem as regras para pertencer aos moldes sociais, mutilando-se identitariamente.

É importante apresentar, brevemente, o enredo do romance. O protagonista é um homem vadio sustentado pela ex-mulher. Ele inventa uma vida diferente, que lhe convém, para cada mulher da sua vida: Eva, a senhoria da pensão deteriorada onde mora, a mãe e a rapariga bonita (uma das cinco que ele acredita serem todas a mesma, aquela com quem ele se envolve).

Após anos casada com o protagonista e tendo ele encostado, Eva conhece um homem no hospital em que trabalhava e separa-se dele para casar-se com o homem. O protagonista se torna nômade, vadio, sustentado por ela. Já ela, passa a ter a vida de luxo que sempre sonhou, com uma casa luxuosa e viagens frequentes ao exterior de Portugal. O protagonista e Eva são extremos "mim" - ele, por perder sua individualidade e confortos intimos, levando uma vida vadia, mas cria histórias para cada mulher da sua vida, a fim de pertencer. Já Eva, para elevar-se socialmente, casa com um homem que descreve como prático, mas ela e o marido mal se conhecem, logo, ela se mutilou identitariamente, abandonando o protagonista a quem ama, para estar com outro homem e viver a vida luxuosa que sempre sonhou.

Um dia, durante um encontro com Eva, pois "portavam-se como amantes" (CARDOSO, 2018, p. 19), avista a primeira mulher que figuraria, com outras quatro, o simulacro da rapariga bonita: a namorada do dono da explanada. Horas mais tarde, avista outra jovem com sua família na praia e acredita que são a mesma. Tentando observá-la sem chamar atenção, acaba machucando-se com um caco de vidro na areia, e o pai e o irmão mais novo da jovem o encaminham ao hospital, após deixar a mãe e a jovem no acampamento em que estavam acomodados, próximo à praia.

Depois desse dia, formou-se sua obsessão pela então rapariga bonita. Passou a vê-la em muitos lugares e, um dia, acreditou tê-la avistado na plataforma de metrô:

[...] viu a rapariga bonita na plataforma de onde
tinha vindo, no cais terminal, nu sitio onde
ninguém espera, por não ter destino. Abriu
e fechou os olhos a pensar que a cara da
rapariga desapareceria como ultimamente
lhe acontecia. [...] Acenou, a rapariga sorriu,
tinha-o reconhecido, era a rapariga bonita que
ali estava (CARDOSO, 2018, p. 180).

Nesse interim, o narrador deixa claro sua obsessão, pois nos informa que ele estava vendo-a em todos os lugares. 
Por fim, conhece uma rapariga bonita com atributos semelhantes ao simulacro por ele criado: jovem e loira. Relacionam-se por um periodo, até ela perceber o quanto ele era obcecado por ela e decide fugir da pensão onde habitavam. Essa jovem relacionava-se com ele pelo conforto material - ter onde dormir, o que comer, ganhar presentes constantemente do protagonista. Não estava com ele por amor. Abdicou de sua individualidade por um conforto básico e pequenos consumismos.

No dia seguinte, ele avista uma jovem loira, vendedora de roupas que visitava a senhoria frequentemente para o exercício da profissão. Acreditou que ela era a rapariga bonita que fugira e chamou-lhe ao seu quarto. Esfaqueou-a e tentou arrancar-lhe o coração, porque a rapariga com quem se envolvera tinha-lhe dito que o coração dela era dele:

Dificil é tirar o coração de alguém. Eu tentei tirar-lhe o coração, se tivesse conseguido ela já não me aparecia, continua a brincar comigo, aparece e desaparece como no princípio, vejo-a muitas vezes, brinca comigo porque sabe que estou à espera, preciso dela na casa nova, já pus o tapete à entrada como tínhamos combinado, [...], quis ficar-lhe com o coração para a ter segura mas não fui capaz, [...]. Ela estava sentada na sala de televisão a falar com a senhoria. Aproximei-me, mas ela fez que não me reconheceu, faz sempre a mesma coisa, fingiu também que não reconhecia o dono da esplanada que andava por lá cheio de fios na mão, se calhar pensou que não percebi que era ele, [...] (CARDOSO, 2018, p. 305-306).

O trecho faz parte de um único capítulo em que protagonista se torna narrador, já no hospital psiquiátrico. Percebe-se sua loucura por acreditar que um dos homens da televisão - que visitavam a pensão para uma matéria sobre sua demolição, injusta segundo a senhoria, necessária segundo a prefeitura - era o dono da esplanada, companheiro da primeira rapariga que avistara. Conclui-se, assim, o simulacro que a rapariga bonita se constrói para o protagonista.

Quanto aos funcionários, como dito, eles surgem nos capitulos em que aparecem as quatro mulheres em uma sala, aguardando para depor ao médico no hospital psiquiátrico. Uma passagem interessante quanto a essa figura do funcionário é a seguinte: "A senhoria levanta-se, segue o funcio- nário nos tornos de verniz branco que já lhe incham as pernas. À frente, o homem caminha mas não se ouvem seus passos, tem solas de silêncio próprias para andar naquele local" (CARDOSO, 2018, p. 43).

Os passos sem som podem simbolizar a invisibilidade social desse funcionário, que é confirmada quando, após Eva reclamar das horas que esperou até então na sala, temos: "O funcionário regressa do corredor iluminado pela clarabóia, não posso fazer nada, não depende de mim" (CARDOSO, 2018, p. 43). Assim, pode-se interpretar que é um funcionário de baixo escalão. Os passos silenciosos também podem indicar a abdicação da própria individualidade em prol das obrigações: trabalhar para pagar as contas (impostos, como Real nos lembra), bem como a subserviência ao espaço em questão: um hospital psiquiátrico.

Outro capítulo assim inicia-se: "Na sala as três mulheres continuam à espera mas já se cansaram de se evitarem umas às outras. O funcionário, que só está ali para cumprir ordens, entra com a senhoria" (CARDOSO, 2018, p. 79). Assim, observamos em "que só está ali para cumprir ordens" o tipo de escalão a que pertence o funcionário, como supracitado. Ele é o proletário, que em nada manda e apenas serve às ordens de pessoas com maior poder no hospital, como o médico para quem elas depõem.

Apesar de parecerem o mesmo, são funcionários diferentes (os citados anteriormente). Nota-se isso na seguinte passagem:

Um funcionário entra batendo com a porta e
as quatro mulheres assustam-se. O funcionário
não é o mesmo que detectou o problema da
identificação nem o que as identificou. É outro,
mas parece-se com os dois primeiros que
também são parecidos entre si (CARDOSO,
2018, p. 115).

Assim, percebe-se a invisibilidade e a desimportância dada a esses homens que, para usufruir do conforto mínimo do proletariado, abdicam de sua identidade a fim de fazer parte da civilização. Figuram o extremo "mim", uma vez que, ao serem todos parecidos, demonstram que passam despercebidos socialmente, ou seja, se encaixam em um molde social. 
Temos, ainda, em outro capítulo, o seguinte trecho:

\begin{abstract}
Um funcionário, que não é o que distribuiu as senhas de almoço e assobiou contente o início da primavera, que não é o que descobriu o problema da identificação nem o que as identificou, mas que é parecido com os três, que também se parecem entre eles, aproxima-se, neste sitio os funcionários são todos parecidos uns com os outros (CARDOSO, 2012, p. 149).
\end{abstract}

Pensando em Marx e Engels, os funcionários todos iguais seriam o proletariado. Já o médico, que ouve as mulheres, o burguês. Assim, essa semelhança entre eles nada mais do que denuncia a dominação do homem pelo sistema social e econômico, a submissão, a alienação e a perda de individualidade - ao ponto de os passos de um funcionário não serem ouvidos e de eles serem todos similares (DANELON, 2006, p. 88). Um trecho que escancara essa condição humana é o seguinte:

O funcionário recomeça a andar, cumpre ordens, há muito que acompanha maquinalmente as pessoas, não quer saber o que se passou, há muito que não é curioso, que não se comove, há muito que é apenas um funcionário que daqui a pouco termina o turno (CARDOSO, 2018, p. 163)

O funcionário - enquanto simulacro - é o extremo "mim" apresentado anteriormente, que mutila a própria identidade a fim de corresponder aos padrões sociais. Isso porque ele perdeu a curiosidade, que é um impulso da fase "eu" do self. Ele é, também, a figura que, por algum conforto minimo, abdica da sua individualidade, escolhe se alienar das situações, submete-se a elas e é dominado social e economicamente, portanto.

Com relação ao médico, a passagem interessante é o que ele pensa após interrogar Eva: "O médico ainda pensa se é feliz e como poderá sabê-lo." (CARDOSO, 2018, p. 185). Assim, mesmo um "burguês", funcionário e alto escalão, desconhece a própria (in)felicidade, pois, por um conforto e luxo maiores, abdica, também, de sua individualidade, submete-se à alienação e a submissão e é dominado pelo sistema econômico e social. Mas, é claro, um status de médico e salário também.

Neste momento convém, inicialmente, apresentar o romance Os meus sentimentos. A priori, convém destacar a forma inusitada do romance. Ele apresenta frases graficamente isoladas que interrompem o discurso da narradora-protagonista e despertam memórias que ela passa a narrar. Algumas dessas frases compõem bordões, como averiguado em estudo prévio. O discurso todo é composto por apenas um período pontuado unicamente por vírgulas, que, com as sentenças graficamente isoladas, perdura por mais de trezentas páginas. Assim, a narradora-protagonista, após um acidente automobilístico na rodovia, apresenta seu discurso em um jorro de consciência, formando um quebra-cabeça a ser montado pelo leitor.

Ela narra, do capítulo um ao seis, o que seria o último dia de sua vida em ordem inversa: 1) o acidente; 2) a perda do controle do carro; 3) parada para comer e encontro sexual com caminhoneiro; 4) jantar no restaurante indiano com Dora, sua filha, e Ângelo, seu meio-irmão; 5) ida ao banco para vender a casa dos falecidos pais e livrar-se, teoricamente, do passado que a persegue; 6) última visita à casa referida. Essa é a narrativa primeira, em termos genettianos.

Do capítulo sete ao dez, consideramos que são projeções de Violeta, pois narra sua suposta morte: 7) como imagina seu resgate; 8) como imagina o dia seguinte a sua morte; 9) como imagina seu velório; 10) como imagina a continuidade da vida de Dora e Ângelo. Colocamos como "imaginações" porque a personagem, capítulos após narrar o próprio resgate, menciona a posição desconfortável em que se encontra no carro após o acidente: de cabeça para baixo, presa pelo cinto de segurança. Assim, temos, no capítulo nove, o seguinte trecho: "parada nessa posição esquisita o tempo mostra-se como nunca o tinha imaginado, dentro dos meus ouvidos grilos, gri-gri gri-gri, os olhos cegos por uma gota de luz" (CARDOSO, 2012, p. 317).

O capítulo onze parece ser seu encontro consigo e o perdão das mágoas do passado. Violeta inicia seu discurso no segundo capítulo "rolo 
sobre as trevas" (CARDOSO, 2012, p. 11). Já no décimo primeiro, ela inicia "rolo pela luz" (CARDOSO, 2012, p. 367).

Agora, voltemo-nos para o quinto capítulo, no qual a presença dos funcionários ratifica a premissa exposta em Campo de sangue. Assim, segundo Bozzo (2020, p. 35-36), a divagação da narradora-protagonista Violeta sobre a vida dos funcionários do banco nos mostra, com clareza, o que ela pensa sobre o cidadão mediocre português. Ela, como extremo "eu", denuncia aqueles que são extremos "mim", como é o caso dos funcionários do banco. O excerto abaixo apresenta o evento periférico que leva a protagonista a imaginar as infelicidades que acometem o funcionário:

[...] o funcionário do banco pede-me que aguarde que os compradores cheguem, a escritura estava marcada para as duas, digo, sim mas com esta chuva é provável que se atrasem, o funcionário fala com exagerada polidez, o notário também ainda não chegou, esta chuva atrasa tudo, as palavras do funcionário são todas ditas no mesmo tom, a educação ajuda-o a calar os inoportunos como eu, retiro-me, o funcionário retoma o trabalho, está aborrecido por o ter interrompido, é a segunda vez que o desvio do computador, da primeira vez falei do temporal, um caos, gosto muito de utilizar esta palavra, caos, um caos, repeti, depois detalhei o caos, quatro acidentes, uma inundação grave e outra menos grave, árvores caídas, estradas cortadas, o funcionário ouviu-me no silêncio educado que matava a conversa, as tragédias que descrevia esfumavam-se na cara imperturbável do funcionário, logo que teve a oportunidade o funcionário regressou ao ecrã luminoso, [...] (CARDOSO, 2012, p. 110).

O ocorrido faz Violeta divagar sobre os possíveis motivos para o mau-humor do funcionário:

[...] o funcionário até podia admitir que detesta o que faz se isso não o revoltasse mais, não fosse a troca do apartamento, o carro novo da mulher, o computador da filha mais velha, o infantário do mais pequeno, as férias de verão, e ninguém o obrigava a levantar-se cedo para se sentar a uma secretária a recolher informações enfadonhas sobre anónimos tão enfadonhos como as informações a que dão origem, o funcionário ficava a dormir todas as manhãs ou partia num cargueiro e dava a volta ao mundo, quando era novo sonhou com isso [...] (CARDOSO, 2012, p. 111).
Depois, a personagem imagina como seria a vida do chefe daquele funcionário:

[...] o chefe do funcionário aborrece-se com os pedidos de crédito monótonos que anónimos igualmente monótonos fazem, não fosse a casa de férias, o monovolume novo, o patrocínio do filho velejador, as viagens da filha poliglota, e ninguem o obrigava a levantar-se todas as manhãs para se enfiar neste gabinete, apesar da secretária e da cadeira regulável, do computador mais potente e da central telefónica, o chefe do funcionário dedicava-se à agricultura biológica, em novo quis ser agricultor e preocupa-se com os nitratos nos legumes, o chefe do funcionário assina os pedidos de crédito e coloca-os em pastinhas com capas transparentes [...] (CARDOSO, 2012, p. 112).

Por fim, ela divaga sobre a vida do funcionário de maior autoridade no banco. A ideia é que a infelicidade reina nas diferentes classes sociais:

[...] também o chefe do chefe do funcionário está maçado com os pedidos de crédito fastidiosos que anónimos igualmente fastidiosos fazem, não fosse o chalezito na neve, a casa num condomínio de luxo, a estada em Londres da filha mais velha, a especialização do filho do meio nos EUA, a mania do mais novo de ser artista, os carros de todos, as motos de todos, os cigarros e as bebidas de todos, as vaidades de todos, ah, os fins de semana com a amante em Nova lorque, e ninguém o obrigava a levantar-se todas as manhãs para se enfiar num gabinete com uma vista tão acanhada [...] I a quantidade de coisas de que as pessoas se convencem que precisam / [...] (CARDOSO, 2012, p. 112-113).

Posteriormente, ainda no quinto capítulo, ela retoma a mediocridade e a falta de individualidade dos funcionários:

[...] não consegui imaginar uma sala com meios funcionários todos iguais, se me detiver em cada um dos meios funcionários talvez descubra qualquer coisa que os individualize mas se os olho de relance nada os distingue um dos outros, / sem a farda as criadas não se distinguem umas das outras, um género muito comum, a pele azeitona e um brilho gordurento, um cheiro a sabão e lixivia, os braços caídos num lamento que não lhes sai dos lábios / a não ser os lugares que ocupam, [...] (CARDOSO, 2012, p. 162-163).

Desse modo, é possivel pontuar que o funcionário visto por Violeta e aqueles que ela imagina, 
todos, por um conforto cada vez maior, conforme o escalão deles, submetem-se à alienação e à perda de individualidade, além de tornarem-se submissos à sua dominação pelo sistema social e econômico vigente. Como afirma Bozzo (2020, p. 36):

Nos excertos, observamos que, para Violeta, as pessoas trabalham para manter um padrão de vida, o que torna a rotina um fardo necessário para bancar os gastos criados. Além disso, a alienação, o consumismo e as profissões indesejadas demonstram o sacrificio feito por essas pessoas para pertencerem, ou seja, optarem por uma vida que não thes traz felicidade, mas patrocina um padrão revelador dos que são o extremo "mim" (ou seja, daqueles que se ajustam excessivamente aos parâmetros sociais). Nesse sentido, as histórias especificas, imaginadas pela protagonista, levam à reflexão sobre "a quantidade de coisas de que as pessoas se convencem que precisam" (CARDOSO, 2012, p. 113). Além disso, o relato das suposições da personagem sobre o funcionário e outros dois chefes imaginários no discurso demonstra como se buscam reproduzir os movimentos de sua consciência. Desse modo, nada do que há nessas narrativas foi verbalizado por Violeta, mas a transcrição dos caminhos de sua consciência despertos pelo descaso do funcionário é feita pelo fluxo de consciência.

Também é possivel notar - sob a perspectiva da narradora-protagonista - que a ambição leva o homem a se submeter, alienar e perder cada vez mais a sua individualidade em prol da manutenção de um status quo que não lhe traz felicidade.

Além disso, estamos diante de uma narradora-protagonista que é extremo "eu" a criticar aqueles que são extremos "mim", ou seja, que se mutilam identitariamente a fim de pertencer. A pertença, sem dúvidas, acorrenta o homem e o leva à alienação, à perda de individualidade e à busca cega por poder a todo custo.

\section{Considerações finais}

Foi possivel perceber que a dominação da natureza pelo homem, o desenvolvimento da tecnologia e da sociedade civilizada e desenvolvida teve seus custos para o ser humano: a alienação, perda de individualidade, submissão e dominação do homem pelo sistema social e econômico. Ainda, que os funcionários de baixo escalão (proletariado) "trocam" sua individualidade e percepção aguçada de mundo por um conforto mínimo, enquanto os de alto escalão (a burguesia) o fazem por luxos, como denuncia Violeta em suas divagações sobre o chefe do chefe do funcionário.

Em nosso corpus, constituido por Campo de sangue e Os meus sentimentos, é possivel observar a representação, na produção romanesca da escritora portuguesa contemporânea Dulce Maria Cardoso, da invisibilidade atribuída a esses funcionários, que figuram os cidadãos mediocres tanto pelo narrador majoritariamente heterodiegético de Campo de sangue até pelas divagações de Violeta, narradora-protagonista de Os meus sentimentos.

Em Campo de sangue, observamos funcionários de baixo escalão (proletários), de pouco poder e todos parecidos - fisicamente - entre si, construindo a figura do funcionário, um simulacro que tira a individualidade de cada um e transforma todos em um só. Já em Os meus sentimentos, por meio das divagações de Violeta, somos convidados a observar que a troca da própria individualidade por poder aquisitivo é incessante: quanto mais se tem, mais se quer ter.

Portanto, foi possivel delinear quem é esse cidadão (português) contemporâneo com o aparato teórico utilizado, bem como averiguar esse sujeito mediano nos romances que compõem o nosso corpus.

\section{Referências}

BOZZO, G. C. B. O que é a não-pertença e como se dá sua construção em Os meus sentimentos, de Dulce Maria Cardoso. Ponta Grossa: Atena Editora, 2020.

CARDOSO, D. M. Campo de sangue. Lisboa: Tinta da China, 2018.

CARDOSO, D. M. Os meus sentimentos. Rio de Janeiro Tinta da China Brasil, 2012.

DANELON, M. Civilização e alienação: diálogo com Freud e Adorno. ETD - Educação Temática Digital, Campinas, v. 8, n. esp., p.85-102, dez. 2006.

GENETTE, G. Discurso da narrativa. Lisboa: Vega, 1986.

MARX, K. H.; ENGELS, F. O manifesto comunista. Ebooks Brasil: RocketEdition, 1999.

REAL, M. O romance português contemporâneo (19502010). Alfragide: Caminho, 2012. 
12/12 Navegações, Porto Alegre, v. 14, n. 2, p. 1-12, jul.-dez. 2021 | e-41665

\section{Gabriela Cristina Borborema Bozzo}

Mestra em Estudos Literários (2019) pela Universidade Estadual Paulista "Júlio de Mesquita Filho" (UNESP), em Araraquara, SP, Brasil. Bacharela e licenciada em Letras pela mesma instituição.

\section{Endereço para correspondência}

Gabriela Cristina Borborema Bozzo

Rodovia Araraquara-Jaú, Km 01

Araraquara, 14800-901

Araraquara, SP, Brasil

Os textos deste artigo foram revisados pela Poá Comunicação e submetidos para validação do autor antes da publicação. 